\title{
RNAi, the guiding principle and keeping family happy
}

\author{
JUAN D. ALFONZO \\ Department of Microbiology, Ohio State Biochemistry Program and The Center for RNA Biology, The Ohio State University, \\ Columbus, Ohio 43210, USA
}

I am a relative newcomer to the RNA field and have knowingly worked on RNA since 1995 . You may say that my interest in RNA literally started with the RNA journal. Having to choose my favorite topic in RNA in the last 20 years is worse than asking a good parent to choose a favorite child. What compounds the problem is that in this particular case the "family" is quite extensive and includes, in the last 20 years alone, 612,536 siblings (entries in PubMed) that harbor the word "RNA." Nonetheless, at the risk of offending my extensive and extended family, choose I must. For me the single most important discovery has to meet two major, yet simple, criteria: 1) it must impact fields beyond that from which the discovery was made; 2) it must generate a principle or concept that can be applicable to thinking about other unresolved scientific questions. Additionally, the discovery may, if providence allows, have some practical applications, although this last point need not be an absolute requirement.

Although many discoveries in the past two decades meet my criteria, none has had more far-reaching implications than the discovery of RNA interference (RNAi) by Andy Fire and Craig Mello. The elegant idea that small fragments of double-stranded RNA acting in trans can effectively shut down the expression of specific genes is surprisingly simple. I do not mean here to suggest a simple mechanism, but rather a simple concept to grasp. Despite the fact that many years have elapsed since the original discovery, introducing RNAi to undergraduate students even today has the same "jawdropping" effect.

By now, we all appreciate that the initial discovery did not end there and quickly many researchers tried to find RNAi in their favorite organism. Of course, the idea that you could, at will, down-regulate gene expression in mammalian cells without having to entertain the sometimes very expensive and time-consuming task of conditional gene knockouts opened new doors. Yet, one of the biggest payoffs of RNAi came with the realization that many of the more eccentric (to be read: understudied) organisms were at the time not really amenable to genetic manipulation. Thus we were for a long time stuck in what I call "model organism heaven,"

Corresponding author: alfonzo.1@osu.edu

Article and publication date are at http://www.rnajournal.org/cgi/doi/ 10.1261/rna.049635.115. Freely available online through the RNA Open Access option. whereby as Monod once put it "what is true of E. coli is true of an elephant." The problem was that there were (and still are) just a few elephants that serve as models. It is here, at this point in time, that RNAi struck a personal chord in my own research. In the mid 1990s, I started working in the "non-model" organism Trypanosoma brucei where I was learning that what is true of T. brucei is not true of an elephant (or of E. coli for that matter), or so it seemed. However, the story is not that simple; it turns out that many discoveries made in trypanosomes do become commonplace in other systems, albeit requiring many years in between. This has led to the general idea that trypanosomes are "weird" and weird they remained as much as they were not easily genetically manipulated. I was right in the middle of this vicissitude while pursuing my postdoctoral training in Larry Simpson's laboratory at UCLA. There, I and other laboratory members had made a number of observations using the tools of Molecular Biology, yet there was no easy avenue to further test such observations in vivo by genetic approaches, so we struggled. Then there came the saving grace of RNAi. Soon after the original discovery, Elisabetta Ullu's laboratory at Yale established that T. brucei had the machinery for RNAi and created a strain where RNAi was inducible by tetracycline (one of the earliest inducible stable RNAi systems). The rest is history and today RNAi in many laboratories, especially those working on the "weird" single-celled protists, is as common as plasmid purification. So much so that RNAi has now become part of the common laboratory jargon where students no longer "perform RNAi of a gene" but rather they "RNAi-it."

The discovery of RNAi exceeds the requirement for my first criterion, but what about the second condition? Where is the major conceptual advance? For this, the lines blur and admittedly RNAi serves to emphasize a larger concept, what I call "the guiding principle." The idea that RNA in trans can recruit molecular machinery to change the function of the RNA acted upon. This, of course, follows naturally from a discovery that is dear to my heart, that of RNA editing by Rob Benne, which at this point we have all come to appreciate (and do I dare say love?). However, a subtle and important concept can be derived from the original articulation of

(C) 2015 Alfonzo This article, published in RNA, is available under a Creative Commons License (Attribution-NonCommercial 4.0 International), as described at http://creativecommons.org/licenses/by-nc/4.0/. 
the term guide-RNA (gRNA) by Larry Simpson to describe those trans-acting small RNAs that carefully and precisely "guide" the insertion of uridines during RNA editing. Here, I must emphasize that the idea of a "guide" was not new even then and had been already discussed in the context of splicing by R. Wayne Davies and co-workers in 1982. RNA binding another RNA to regulate gene expression was not a new idea either, going back to the original proposal by Monod and Jacob and later in the context of plasmid copynumber control in the early 1980s. What makes the guiding principle different is the idea of recruitment of additional machinery made mostly of proteins, perhaps reminiscent of a point in time where RNA and proteins were equal partners in a joint venture that moved us from the RNA world into the extant RNA-protein world.

Nowadays, many RNAs are guiding different biological processes; for example, snoRNAs guide modification and processing of ribosomal RNA, siRNAs guide target RNA cleavage, double-stranded RNA guides epigenetic control in plants, snRNAs guide splicing. Of course, more subtle examples of guiding have existed for a while and it can be argued that even SRP and certainly telomerase RNA guide structure/ function information, albeit at different levels (translation vs. DNA replication). Still, RNAi may just be the poster child for "guiding." Arguably, the discovery of CRISPR/CAS system in Archaea and Bacteria was easy to digest based on the precedence set by RNAi.

Given that guiding, as discussed here, implies the coupling of based-pairing interactions and structures to recruit machinery, the sky is then the limit for the guiding principle. What the future holds is the challenge to elucidate every possible guiding system resting assured that plenty of examples of "guiding" still lurk in the entrails of cells. Soon enough, RNA may be found to guide other RNA modifications, protein modification, lipid remodeling and, why not, even sugar chemistry, what a sweet story indeed that would be.

In a way RNAi, my chosen "sibling," together with the "guiding principle" has significantly affected, and will continue to affect, our scientific lives in more ways than meets the eye. I write these few lines with the hope that my extended family remains happy with my choice even as we rejoice in this terrific discovery of RNAi. So, next time your favorite gene (or sibling for that matter) does not behave well, my recommendation is to RNAi-it and keep on celebrating. 

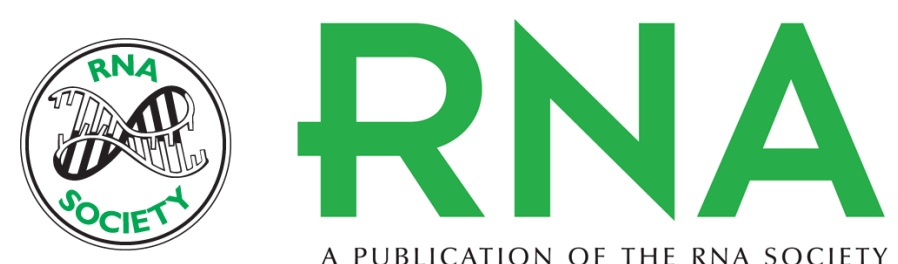

A PUBLICATION OF THE RNA SOCIETY

\title{
RNAi, the guiding principle and keeping family happy
}

\author{
Juan D. Alfonzo
}

RNA 2015 21: 555-556

Open Access Freely available online through the RNA Open Access option.

Creative This article, published in $R N A$, is available under a Creative Commons License

Commons (Attribution-NonCommercial 4.0 International), as described at

License http://creativecommons.org/licenses/by-nc/4.0/.

Email Alerting Receive free email alerts when new articles cite this article - sign up in the box at the Service top right corner of the article or click here.

To subscribe to $R N A$ go to:

http://rnajournal.cshlp.org/subscriptions

(C) 2015 Alfonzo; Published by Cold Spring Harbor Laboratory Press for the RNA Society 